\title{
ARTE E IDEOLOGIA
}

\author{
Flávio R. Kothe
}

\begin{abstract}
Resumo
A obra para ser arte precisa ir além dos ideologemas nela contidos. A própria teoria estética pode ser ideologia, não apenas sendo a propaganda manifesta de uma convicção religiosa, moral ou política, mas também na estrutura profunda: a obra ser considerada arte serve para disfarçar o repasse de crenças e valores, a propaganda de uma escola, nação ou época. Se o transmitido é apenas ideologia, ela precisa ser mais camuflada quando o espírito esclarecido avança. Para conseguir maior objetividade na avaliação das obras precisa-se do método comparativo, examinando as variantes em torno de um tema ou topos.
\end{abstract}

\begin{abstract}
A work to be art needs to go further than the ideological moments that it contains. The aesthetic theory itself can be ideology, not just being the explicit propaganda of a religious, moral or political conviction, but also in its deep structure: that the work should be considered art serves to disguise the transmission of beliefs and values, the propaganda of a school, nation or period. If the transmitted is just ideology, it needs to be more disguised when the critical mind develops. To get more objectivity in the evaluation of works of art it is necessary the comparative method, examining the variants of a theme or topos.
\end{abstract}

\section{CRONOTOPOS E TÉCNICA}

A comparatística na arte deixaria de cumprir seu passo maior se servisse só para decifrar relações internacionais: ela seria então um suplemento à história nacional ou parte de uma historiografia globalizada, reduzindo-se a um capítulo de um discurso que não tem na arte, e sim na política, seu escopo principal. A comparatística precisa, sem se restringir ao nacional, comparar as artes entre si, em obras significativas, para daí galgar os pináculos das grandes obras. A obra de arte tem em si uma política, uma arquitetura interna, uma estrutura de poder: isso é algo tão intrínseco que não se reduz a palavras soltas ou gestos ocasionais, embora possa se mostrar neles com mais clareza. Ela não ser como o mundo circunstante já é um gesto ético. Sua moldura é a negação do circunstante, para a afirmação do espaço de significação da obra. 
É preciso não perder o foco ao tentar delinear a grandeza de obras mediante o confronto entre elas. Há um ponto em que a comparação cessa, e se inicia o diferenciado do maior. A comparação pode ser um meio de superar limites do conceito e da lógica abstrata, para decifrar horizontes que a arte alcança, mas são negados ao entendimento conceitual: não é, portanto, apenas mais um método para a crítica de arte. Ela usa os métodos para buscar algo além deles. Ela refaz de outro modo o feito na obra para buscar o sentido buscado pelo artista, reinterpreta uma interpretação do mundo.

É como se a vocação primária da comparatística fosse desviar-se de si mesma, encontrando sua razão de existência em algo outro, uma qualidade que não é proporcional à quantidade. Baseia-se antes numa sensação de grandeza da obra que na lógica formal do método. Pouco sentido há em comparar por comparar, mais enganoso ainda é inventar aproximações entre obras que não têm nada a ver umas com as outras.

Ao se ocupar com as relações entre as artes e suas interações no espaço e tempo, a comparatística deveria aflorar os deslocamentos e as deformações das dominantes estruturais, tanto dentro do sistema das artes e escolas quanto dos cânones nacionais. Quando um autor menor retoma outro, ele se fixa no horizonte dele como limite a ser almejado: tenta imitar um autor menor ou então aspectos menores de um autor maior. Faz o que está dentro de suas possibilidades, não se pode esperar mais do que ele pode dar. Sob a homenagem existe a confissão de uma limitação. Trai o sentido mais próprio da apropriação do alheio: ir mais longe que o já feito. O bom intérprete procura ir pela obra mais longe que a obra para poder chegar até ela. Ele é um parceiro do artista.

O gênio artístico retoma obra $\mathrm{s}$ de outros autores porque percebe algo que ainda não foi dito e que lhe parece relevante. Cita para negar. Ama para acabar traindo. Ele não nega por maldade, mas porque o outro não lhe basta. Sua obra se torna única por essa diferenciação. Ele só vai conseguir se tornar um mestre se tiver tido mestres, mas só alcança a maestria quando percebe suas limitações e, desamparado, tem de assumir a necessidade de abrir caminho para outros horizontes. Ninguém nasce sabendo: ele precisa chegar à altura do mestre para poder ultrapassá-lo. O melhor discípulo acaba apunhalando o mestre pelas costas.

Há uma contradição na "filiação por influência": quem segue à risca a receita do mestre, coloca-se como menor que o mentor, como se fosse um satélite, a refletir 
palidamente sua luz, sem ter luz própria; quem é apenas rebelde prova que não merece o mestre; o gênio criativo demonstra sem dizer que o mestre é menor, não é um pai digno desse filho que se aproximou dele, pedindo-lhe a bênção. O grande discípulo não pode seguir o mestre, pois seria repetir caminhos já batidos. Ele é quem vai, cuidando da própria obra, apunhalar o mestre pelas costas.

Se não fizer essa "traição", não vai chegar a si mesmo. Ou ele trai o mestre ou trai a si mesmo. A encruzilhada é difícil, mas quem tem o impulso inato à criatividade diferenciada atropela quem se puser no seu caminho. Discípulos menores são menos prezáveis porque eles estacionam na postura imitativa, mesmo que se tornem mestres de imitadores ainda menores que eles.

$\mathrm{Na}$ história da arte de uma região pode-se ler sua história social. A sociologia da arte reduz as obras, no entanto, a documentos de um momento e lugar, como se a validade delas fosse proporcional à mímese do status quo, como se a obra só valesse como testemunho sintético de uma época e não fossem capazes de dizer algo mais. Se, pelo contrário, certas obras são grandes porque ultrapassam o cronotopos de sua gênese: tanto a sociologia da arte quanto a história da arte não captam isso, desviam do principal ao acessório. Os fatos sociais são sempre singulares, ainda que apreendidos mediante conceitos genéricos, enquanto as obras de arte expõem no singular algo universal. A história, para ser exemplar, precisa da narrativa. As grandes obras são algo mais que o retrato de uma pessoa, a reprodução de uma paisagem, a cópia de frutas e insetos. $\mathrm{Na}$ singularidade elas expõem a transcendência, a intersecção com o ontológico.

Elas também não são apenas meios corpóreos de transmissão de "ideias filosóficas": a filosofia da arte também trai a arte, pois quer fazer dela uma serva, que sirva aos propósitos da filosofia, obviamente considerados superiores por esta. A alegoria é um limite a ser ultrapassado: na concepção neoplatônica, o concreto serve aí só para remeter ao abstrato, que é o realmente importa. Assim como a teologia quer se ver representada em ícones, a filosofia quer sugar o sangue das obras de arte para se alimentar. Em sua existência supõe ter uma ideia anterior à representação, por isso supõe apenas se apropriar do que é seu de direito. Como numa enciclopédia, a ilustração pode ser de um modo ou de outro, desde que corresponda ao conceito prévio. A obra seria então apenas uma demonstração, uma ilustração de uma verdade filosófica. Ora, as 
grandes obras de arte costumam sugerir algo diferente do que a teologia e a filosofia pretendem. É preciso desencavar o que fica encoberta por suas visadas.

Quando Shakespeare estuda o ciúme no Otelo, o amor em Romeu e Julieta, a vingança em Otelo, a ambição em Macbeth, ele vai além de uma alegoria dessas paixões. Cada uma das obras pode ser lida de outras perspectivas que não apenas a da paixão principal nelas elaborada, sem que essa diferença seja uma redução delas. Otelo mostra que é impossível a um estrangeiro penetrar no mundo fechado da aristocracia; Romeu e Julieta, que o poder político é mais forte que o desejo dos indivíduos; Macbeth, que a ambição desmedida leva à loucura. Os personagens não são aí apenas marionetes de uma entidade metafísica: são singulares e vívidos. Eles permitem várias leituras porque são contraditórios. Para serem assim, não podem ser uma noção simples.

A divisão entre obras que parecem realistas e obras de fantasia não percebe que nestas há realidade, enquanto aquelas não são "A realidade", "o real". A arte não pode ser apenas mimética, pois se não ela não poderia ser significativa, seria apenas a reprodução do existente. Quem apenas copia trai o traço mais significativo. É preciso deslocar, deformar, excluir, sintetizar, para torná-lo peculiar, significativo, sugestivo. Embora haja uma tendência à regionalização da arte, as grandes obras se contrapõem à mera mímese e constituem um horizonte irredutível à propaganda de uma região, de um partido ou país.

Mesmo que obras operacionalizem ideologemas, elas são arte à medida que transcendem o horizonte deles, sem que se reduzam à postulação de outro. Há diferença fundamental entre operar ideologemas e ter no ideologema a estrutura profunda: é a diferença entre arte e trivialidade. Quem é dominado por uma ideologia não percebe que é ideologia o que o domina. Só quem não crê nela consegue ver sua limitação. Não há liberdade na crença: ela expressa a falta de liberdade interior.

A teoria estética também pode ser uma ideologia, não apenas no sentido de ser a propaganda manifesta de uma convicção religiosa, moral ou política, mas também na estrutura profunda, repassando de forma disfarçada crenças e valores. Ela pode ser a propaganda de uma escola ou época. Dizer que arte é a expressão sensível da ideia ou da verdade, sendo estas confundidas com uma crença religiosa ou moral, constitui ideologia, que se apresenta de modo tanto mais camuflado quanto mais o espírito esclarecido avança. Na narrativa trivial, a crescente diversificação das estruturas de 
superfície serve para disfarçar e tornar mais eficaz uma estrutura profunda que seja um postulado ideológico. Isso é mais relevante que ideologemas localizados numa fala de personagem, num ícone, numa veste. A ideologia é tanto mais eficaz quanto menos aparece como tal.

Quando se diz que a obra de arte se constitui na aparição sensível da ideia (mesmo que sob outros termos como gesto semântico, ícone ou significado encorpado), já se está mergulhado na tradição neoplatônica, como se houvesse separação absoluta entre ideia e existência, entre corpo e alma, matéria e espírito, terra e céu: tem-se aí, primeiramente, uma "ideia" metafísica e depois a sua encarnação. Seu modelo é teológico: "o espírito que se fez carne e habitou entre nós”. A “expressão sensível” só vale, nessa lógica, pela "ideia” que se supõe escondida por trás dela, como a alma imortal no corpo. Quando o corpo morre, a alma vai para o além, supõe o cristão, e lá se preserva; quando o artefato é destruído, a obra perece. A arte e a ideia são tão mortais quanto os deuses imortais. A cópia só preserva a obra perdida se for equivalente a ela.

Todo artista tem de ser artesão, mas raro o artesão que chega a ser artista. O artesão faz um objeto decorativo programado. A obra do artista, ao ser feita, passa a ter cada vez mais autonomia diante do autor, como se fosse mais que uma coisa: um ser vivo, com demandas próprias. A obra de arte é mais que uma coisa em que se insuflou um espírito que nela se expressa. Ela é um tenso campo energético.

A obra se obra através do artista. Ele é o servo da obra, supondo ser seu senhor. A obra faz o autor que a faz. Ela o usa para se fazer e depois o dispensa, passando a ter existência própria, se for boa. Só assim consegue ela se separar do cronotopos de sua gênese para aparecer viva em outros tempos e lugares.

O preço disso para o artista é terrível: ele se torna um estranho ao seu meio e momento. A criação se dá em estado de solidão e abandono. O artista só pode contar com ele mesmo. Para ser depois abandonado por sua obra. Ela lhe dá as costas, ingrata. Se não o apunhalar pelas costas, ele pode se dar por satisfeito. Enquanto ele a está fazendo, ela é como uma filha pequena, que ainda precisa crescer e amadurecer. Depois ela cai na vida, vai para o mundo. $\mathrm{O}$ artista gostaria de pintar o mundo todo, expandir sua obra a tudo, mas ela se faz na limitação. Ter nos limites o espaço de múltiplas possibilidades, tendo de escolher e fazer a melhor, é a extenuante tarefa do autor. A falta de formação filosófica impede que se percebam os temas existenciais mais prementes e 
se formulem as obras que os expressem. Falta coragem para virar pelo avesso a tradição milenar de imagens e crenças. A arte contemporânea está aquém de suas tarefas.

Vai-se o homem, ficam as obras. Será que o artista quer salvar sua alma depositando-a em obras? Será que ele não se liberta dos jesuítas? Proust diz que o leitor usa o autor como óculos para ler a si mesmo e que as obras vão morrer também. Muitos gostariam de ser imortalizados pelas obras que fizeram. Em geral não sabem o preço que o gênio paga para fazer uma obra transcendente. Quando os amigos se forem, eles se irão com eles. Não sabem o preço pago pelo gênio em função do tremendo esforço que faz para parir uma obra maior que ele.

A partir dos estudos comparativos, abre-se caminho para construir uma história geral de cada arte e de todas as artes, bem como para desconstruir a visão que se costuma ter do cânone nacional, passando de um ditado dogmático interno para uma perspectiva mais crítica e abrangente. Faz-se uma reavaliação de todos os valores. Muitos grandes nomes se desfazem no ar como vampiros atingidos pelo sol. Aqui e ali algum nome obscuro mostra ter luz própria. Também se passa a ver obras antigas sob ângulos novos, fazendo leituras inusitadas. A pretensão de querer uma "história geral", que abranja a totalidade dos fenômenos artísticos, tem um fulcro totalitário. Não é possível abranger tudo. Finge-se que uma parte seja o todo e que o que ficou de fora não tem valor efetivo. Sob a aparência de erudição, institui-se a injustiça.

Embora a boa obra de arte demonstre o seu valor de modo diversificado com o transcurso do espaço e tempo, sendo surpreendente o encontro dela fora de sua origem, costuma-se limitá-la à sua gênese. Isso ocorre ao se propor a periodização das artes em complexos como escolas e estilos. Perde-se a especificidade da evolução e a diferenciação da grande obra. Não é grande a obra que se reduz a documento de uma escola: essa redução é, porém, que norteia a historiografia. Há obras que envelhecem, se mostram banais; outras, que adquirem mais vigor com o tempo ou que são mais bem recebidas em outros lugares. $\mathrm{Na}$ outra ponta, acaba-se considerando arte (ou arte a ser considerada) apenas aquilo que se "consome no mercado".

Supõe-se que essa periodização nacional coincide com a periodização geral. Há em geral diferenças marcantes e não ocasionais entre o que acontece nas metrópoles e o que acontece nas periferias culturais. Houve, por exemplo, mais que atraso do romantismo brasileiro em relação ao francês, e deste em relação ao alemão: o brasileiro 
fez uma conversão à direita do que havia sido senso crítico na Europa, o francês traduziu o vigor crítico de Jena para o background católico. Se as distâncias encurtaram com a tecnologia, as distorções feitas pelas lentes que filtram os dados continuam intensas. Mudam-se até características básicas do que mantém o mesmo nome: a epopeia não é mais declamada, o soneto não é cantado.

Há uma especificidade dos países periféricos que não é percebida nas metrópoles e que em geral também não interessa a elas. $\mathrm{O}$ que realmente conta é, na prática, a produção dos países mais desenvolvidos. Pode-se, na periferia, fazer de conta que isso é mera arrogância ou que eles têm de fato razão em sua atitude. Tais situações, replenas de preconceitos e prejuízos, são, porém, históricas e, portanto, transitórias. Isso não significa que eles acabam, mas apenas que mudam.

Há ignorância em dupla mão: nas metrópoles, há menosprezo pela produção dos países menos desenvolvidos; nestes, não se costuma ter acesso ao ápice do que se passa nelas e então eles supõem que neles se esgota o que importa. A retificação não se dá, no primeiro caso, só insistindo na densidade da produção da periferia nem, no segundo caso, suplementando as postulações das metrópoles com alguns adendos exóticos da periferia. Ignora-se o que interessa ignorar. Com o desenvolvimento da internet, da mídia, do turismo, do intercâmbio acadêmico e do comércio internacional, essa situação vem se modificando, embora, por exemplo, nas escolas do Brasil só se ensine o cânone literário brasileiro e só pintor brasileiro circule no mercado do país.

O narcisismo de cada "nacionalismo" impede a visão de suas limitações e seus defeitos, acaba levando a uma não percepção equilibrada de suas qualidades e limitações. Ela inventa para si um passado ideal e heroico - como é o caso do indianismo brasileiro —, sem reconhecer o que significa tal invenção. Ela não costuma ser vista como "inventio" e sim como "factum". Não há, porém, puros "facta". Quem crê não sabe que crê: ele imagina saber a verdade, mesmo que a única verdade seja aí que ele crê. Quanto menos se percebem as próprias limitações tanto mais se cai nelas. $\mathrm{O}$ que parece patriótico acaba sendo prejudicial ao desenvolvimento, como também é o fascínio abobado pela metrópole. Com a idealização prejudica-se o que com ela se quer conseguir.

Na era em que a técnica substitui o pensar, o profissional só se especializa num setor, como se, por ter um diploma, soubesse tudo sobre quase nada, sendo nada todo o 
resto. Quem atua em determinado ofício deixa de perceber o que se passa em outros setores e quais diretrizes imperam na área da especialização. É levado a achar que a ideologia do seu métier seja a verdade do todo. Não percebe que o "seu todo" não é tudo. Em si, ele é pouco. Cada todo faz parte de um todo maior.

Quanto menos o "entendido" perceber suas limitações, mais acredita que aquilo que ele supõe saber é tudo o que importa, está tudo o que importa: só por ser o que importa a ele, supõe que seja um garante de superioridade. O parcial que não se vê como parte de um todo maior, supondo que é tudo, não consegue decifrar direito o seu todo. De repente pode ficar perplexo pela interferência de fatores não previstos no seu sistema. Não há um "todo" último, um "universo" fechado: tudo se perde na infinitude, que está presente em tudo. Diploma na parede é um índice de limitação. Grandes nomes não precisam usar títulos.

Arte de primeira grandeza perturba o paradigma, pois, por mais que se tente reduzi-la à subserviência, ela sempre guarda a distância da irredutibilidade quanto ao que dela quer fazer a manipulação ideológica. O ódio que isso provoca faz com que seja difamada, soterrada, expurgada, mas há uns poucos que podem recobrá-la e preservá-la, pois encontram nela uma grandeza que valida a existência. Só quem tem em si a matéria que pega fogo com a fagulha do artista consegue acesso ao horizonte mais elevado que se configura na obra. Há algo de grandioso nisso. Todavia, compreendê-lo demanda perceber limitações que permeiam a obra, ou seja, que ela só é grande enquanto perdura sua finita abertura para a infinitude.

Nos sistemas nacionais de artes, as categorias analíticas partem da premissa de que a nacionalidade é prioridade na arte, como se tudo nela girasse em torno dela. Como pode isso se sustentar, porém, se o "nacional" não apreende a artisticidade e não passa de um elemento eventual, cartorial, extra-artístico? Um cânone nacional a dirigir a arte não consegue perceber seu caráter limitado. Ele usa o artístico para servir às políticas do poder.

Há muitas obras que permanecem assim, perpassam décadas promovidas por servirem ao poder, aparecendo como arte sem ser. Consagradas por sua subserviência, abdicaram da liberdade de dizer o mais grave, preferindo ficar de acordo com as proposições da governança. Impérios já se desfizeram, sem que obras de arte neles produzidas perdessem sua validade; outras obras há que se tornam fumaça quando se 
desfazem as instituições que as sustentavam e que elas legitimavam. Quanto mais a obra faz o jogo do poder, mais este promove como arte o que deixou de ser arte para ser apenas propaganda. $\mathrm{O}$ grande artista finge que serve ao poder para poder se servir do poder para poder fazer sua arte.

\section{MONUMENTO E PROPAGANDA}

No passado, igrejas e palácios eram os locais em que se preservavam obras de arte, para legitimar seus ocupantes. Sendo espaços de culto, gerou-se um culto às obras neles expostas, como se não fossem propaganda. Até hoje a história da arte não se descontaminou disso. Palácios foram feitos como templos habitados por gigantes. Museus modernos precisaram se livrar do modelo palaciano. Nem palácios nem templos foram feitos para expor arte, mas para propor cultos mediante objetos de culto. O culto não se voltava ao "objeto", e sim a divindades em seus representantes. Divino aí era o deus, o rei, o aristocrata. Cada um representava mais que ele mesmo: uma força da natureza, uma tendência humana, um país, uma região. Isso contaminou a concepção que se tem de arte: representação concreta de uma ideia abstrata, uma alegoria. $O$ símbolo enfatiza mais o signo concreto, mas para remeter ao geral representado.

Países ditos civilizados instalam museus em prédios artísticos, gerando respeito ao país e renda com turismo. Igrejas usam as artes para reforçar a crença e a casta sacerdotal. Movimentos políticos e sociais procuraram se estetizar, para auratizar seus princípios. O estético causa aí comoção nos adeptos como se arte fosse. Ele é um belo embrulho para presentear o que ele não é. Serve para beatificar o que santo não é. Promove obras menores a grande arte, para que a crença nelas subjacente se reforce. Daí se deriva uma teologia, para justificar a crença, como se fosse lógica. Sob o pretexto moralizante, há interesses que levam a vantagens pessoais e grupais. Tem-se uma "kalokagathia" às avessas, para o que não é verdadeiro nem justo, mas consegue ser kitsch querendo ser belo. É a "arte que o povo gosta”. Deforma o gosto.

Quanto mais isso aparece, menos se enxerga; tanto mais é feito quanto menos se escapa à sua presença. Hotéis, consultórios, bares e lugares semelhantes querem uma decoração boa e barata, mas arte não é decoração nem costuma ser barata, já que muitos 
a querem. Quanto maior a possibilidade de roubo tanto mais barata a decoração. O artista precisa fazer algo tão bom que o falsificador não consiga fazer igual.

A pretexto de cultivar o sagrado, templos e terreiros podem estar repletos de má pintura, má escultura, mau odor, má arquitetura, mau teatro, má cantoria, sem que falta de artisticidade seja questionada. Supõe-se que o que importa é a entidade divina invocada. É um modo de estragar o estético e proclamar isso como divino, o que corresponde a sistemas que precisam do injusto como justiça, da mentira como se verdade fosse. Predomina a crença, não a razão. Com fé demais, os fiéis não decifram o evidente. Por outro lado, esses espaços geram oportunidade para que boa arte se desenvolva. Confunde-se, porém, o sacro com o estético.

Crenças são desejos incapazes de entender o que os provocam. Deformam e escamoteiam seus reais motivos. A verdade nua e crua se torna insuportável, como se fosse cruel e não cirúrgica. A hermenêutica filosófica, ao contrário da exegese teológica, propõe-se a questionar seus pressupostos: ao longo do estudo da obra, não pode se restringir à análise para melhor entender o texto, não apenas o escrito com palavras, mas toda obra significativa, cujo sentido hermético resiste ao esforço de deciframento. Essa tensão do fracasso iminente a obriga a se questionar.

Há, porém, belas esculturas e pintores em templos, belas melodias em terreiros. Há sintomas na consagração de obras em museus que garantam que todas elas são artísticas? O museu aparenta preservar o que merece, mas outras obras, diferentes, poderiam estar nele. Ele é que cria, pela preservação, a impressão de mérito artístico. Cada obra precisa provar ter merecido a preservação, mas o museu não é apenas a expressão disso. O poder que se impõe no espaço da consagração consagra o que serve para consagrá-lo. Embora ele não seja bobo ao ponto de colocar qualquer coisa, pois necessita de obras de qualidade para dizer que ele próprio tem qualidade, sua motivação principal não é artística, e sim reforçar o que lhe dá poder.

Se isso não se baseia unicamente no critério estético, seria possível adotar como regra hermenêutica sua antítese? Ou seja, as obras em museus serem suspeitas de subserviência e conivência com o poder estruturante, devendo melhores obras ser buscadas fora dos museus? Nas academias de letras não se tem necessariamente os melhores escritores de um país. Na esclarecida Paris, foi preciso fazer uma exposição 
dos excluídos para que aflorasse o melhor da pintura que lá estava se fazendo. Perturba o poder ele supor que seja exercido como missão divina.

Se não fosse um processo natural de acomodação, em que as peças estacionam nos museus, boas obras poderiam ser aquelas que continuam prestigiadas por outro regime e país que não aquele de onde elas ser originam. Assim, se o país passa da monarquia à república ou se um museu francês importante preserva e destaca uma obra italiana ou holandesa, pode-se confiar mais em sua qualidade; se nas salas de concerto de um país se tocam músicas de outro, idem; se uma Igreja consagra e adota música oriunda de outra, é porque reconhece qualidade. Há obras de outros países que são promovidas, no entanto, por boa vizinhança, um critério político e não estético.

Obras do mesmo autor não têm todas a mesma qualidade. Nos leilões de arte, os compradores procuram fazer a escolha certa, seguindo paradigmas em que qualidade estética procura ser traduzida em quantidade de dinheiro. Há disputas no sentido de um bom retorno, ou seja, obter o máximo de arte com o mínimo de dinheiro ou ter um retorno máximo para o investimento feito. A obra é vista como mercadoria, como se fosse um papel na bolsa. A arte parece ser o investimento mais incerto, de maior risco, mas que também pode dar os maiores resultados. Como não há um grau maior de garantia, ela não é um investimento, mas se torna quando investimentos em bolsas, títulos ou imóveis se tornam muito incertos.

Quando se gasta muito dinheiro, parece que se obteve muita arte, mas pode ser um engano. Não há uma relação direta entre preço e qualidade, mas em geral as obras de maior qualidade alcançam preço maior. Tende a haver uma coincidência nas escolhas dos conhecedores. A boa obra se destaca, mesmo que isso não seja percebido por todos. Por melhor que seja a cópia, ela não tem a perfeição do original. $\mathrm{O}$ falsificador de telas ou esculturas presta um preito à qualidade do original, mas tanto o prejudica ao gerar desconfiança quanto propõe como melhor o que é pior. Nas outras artes não há tanta falsificação de autoria. O autor só deve se propor a fazer uma obra quando tem algo relevante a dizer. Deve fazê-lo do melhor modo possível, para que sua perfeição a proteja. Quando há erros evidentes, a obra se desqualifica. Nela nada se deve poder mudar, acrescentar ou tirar sem que ela fique pior. Pode-se fazer outra obra ainda melhor a partir dela, mas como outra obra. Originalidade não é busca forçada, tortura, 
mas decorrência natural de um modo diferenciado de ver o mundo e saber fazer sua representação.

Há fatores não estéticos que interferem nos preços, quando leilões servem para lavagem de dinheiro ou para abater impostos, quando há a fetichização de obras e a mistificação de certos artistas, quando o mercado fica inflacionado, quando há o predomínio da propaganda ou da moda. Tanto se pode pagar demais por obras de valor menor quanto se pode menosprezar a qualidade de obras que não estão de acordo com o gosto do meio. Pode haver a súbita valorização de alguns artistas, com sua doença ou morte, como pode haver desvalorização por boatos de falsificação ou por se badalar uma nova moda. Um autor não ser valorizado num meio não significa que ele não tem valor, pois a produção dele pode estar longe das expectativas do mercado, do gosto imperante no meio. Há autores locais que só tem preço no local.

Há enormes interesses comerciais na qualidade estética. Leilões, vernissages e galerias são modos de transformar obras de qualidade única numa quantidade social sob a forma de preço. O "preço", ainda que individual, é sempre um "valor médio". Ele não se mede em arte, porém, pelo tempo social médio gasto para a produção do bem. Ele é proporcional ao talento, ou melhor, da avaliação social média que é feita do talento, derivada da tensão entre demanda e oferta. Se é possível chegar a um preço, que não é calculado pelo tempo social médio de produção, é porque a obra não é tão "única", e sim antes "equivalente". Quem não consegue uma obra X pode comprar Y por quantia parecida. A venda de uma tela contamina o metro quadrado das telas do mesmo autor. Daí a ânsia de conseguir o máximo de preço, mas também o corretivo de outras não serem vendidas.

Obras do mesmo autor e de diferentes autores entram como que numa roda viva dos compradores: se não se pode ter a obra tal, pode-se conseguir outra que possa ser considerada equivalente ou até melhor. Embora diferentes, elas estabelecem uma equivalência: não são propriamente substituíveis, mas capazes de serem objetos do desejo. Seria como se fossem as mulheres de Don Juan: em cada uma se guarda uma pequena diferença, mas, como todas têm alguma, todas se equivalem nisso. Se ele está com uma, poderia estar com outra, pois não é de nenhuma. A grande ausente permanece distante, já que deixaria de ter grandeza utópica se não fosse apenas ideal. 
O dinheiro que compra uma obra pode servir para comprar outra. $\mathrm{O}$ mercado dissolve o caráter único da obra dando-lhe um preço, que resulta de comparar equivalências. O "único" quando absolutizado é um platonismo em que nem Platão acreditava.

Quanto maior a demanda e menor a oferta, tanto mais elevado tende a ser o preço; quanto menor a demanda e maior a oferta, tanto menor o preço. A força da lei econômica pode ser contida por outras leis. $\mathrm{O}$ autor gostaria de receber o máximo pelo mínimo de obra, enquanto o comprador gostaria de ter o máximo de obre pelo mínimo de preço. Predestinados ao conflito, precisam chegar a um acordo. O "bom negócio" se dá quando cada um acha que passou o outro para trás. Os preços mínimos em leilões se baseiam em vendas anteriores do artista. A lei da oferta e da procura não explica bem, no entanto, os preços na arte. Ela mesma camufla como trabalho social médio o que não é um trabalho mediano.

O grande artista não tem um "equivalente". Ele ter um modo peculiar de obrar torna suas obras reconhecíveis, mas não garante por si qualidade: pelo contrário, tende a indiciar que se trata antes de um artesão. Um artista importante numa região pode não ser (tão) reconhecido em outra. Os preços nas artes plásticas extrapolam por fetiche. Perdem a relação com trabalho e talento. O comprador é induzido a comprar mais que a obra: ela parece trazer consigo outros valores: prestígio, fama, estar na moda, ser benemérito, etc. Em suma, ser melhor que os outros.

As obras costumam ser adquiridas pelo nome do autor, pelo enquadramento numa escola ou num estilo, pela região ou nacionalidade, por uma recomendação, pelo preço e assim por diante: ou seja, por não serem "únicas". Se o comprador não tem informações adicionais sobre o autor, se ele se vê confrontado apenas com a obra sem saber de quem é, ele fica em geral inseguro quanto à qualidade dela. $\mathrm{O}$ grande desafio é detectar a qualidade na obra e pela obra, sem qualquer referência externa.

Se cada obra tem um comprador virtual, como se ambos se procurassem, isso pode aproximar da obra média o gosto mediano e da obra diferenciada o gosto peculiar: o vendedor, à espreita para encaixar o negócio, procura fazer essas aproximações. Pode ser gerada repulsa entre obra e dono, passando ela como que a procurar novo dono, que a proteja do abandono. O colecionador procura preservar a obra para o futuro, tirando-a do desabrigo. Ele procura reunir boas lembranças e evitar o que lhe seja incômodo. 
Num país sem grande tradição de colecionismo, de brancos ricos broncos, as famílias geralmente não têm grandes obras a transmitir e não têm o costume de montar um bom acervo de quadros, esculturas, livros. Quem teria dinheiro para a arte geralmente não está interessado nela nem sabe comprar bem. O gosto popular, que muitas vezes não chega sequer a caiar o barraco, ocupa as paredes com reproduções de má qualidade. Quando o dinheiro mal dá para sobreviver, arte vira luxo. A qualidade da arte de um lugar é um índice da qualidade de vida.

A aristocracia europeia colecionava arte; a oligarquia rural brasileira, não. Nas zonas de colonização alemã, as paredes ostentavam lúgubres retratos nupciais e uma péssima reprodução da Última Ceia com varas atrás para bater nas crianças. Igrejas foram por séculos o único lugar para as obras. Isso lhes deu prestígio. Um país menos desenvolvido, não tendo grande acervo em galerias e museus, também não desenvolve a formação do bom gosto nas escolas. O ensino ficou marcado pelas ordens religiosas, que não pagavam pelo trabalho de seus membros, os quais tinham de lecionar, quer tivessem vocação ou não. Exposições, teatros, concertos e balés ainda não fazem parte da pedagogia local. Não existe a convicção política de que a formação do gosto faça parte da cidadania.

Os leilões em países ricos atingem cifras impensáveis em países pobres. Países com grande oferta de obras e tradição têm mais probabilidade de ter melhores obras. $\mathrm{O}$ acaso do gênio precisa de um sistema comercial que o sustente. $\mathrm{O}$ gosto que não dança conforme a moda pode encontrar obras de boa qualidade a preço menor, assim como a moda pode induzir a pagar mais pelo que vale menos.

Teorias e histórias da arte que reduzem a arte a alguns "ícones" prestam um desserviço à arte, enquanto servem aos interesses dos proprietários desses ícones: Estados, Igrejas, museus, galerias, bancos, colecionadores. A população como que fica presa à opção de não ter arte, já que não pode possuir as obras badaladas como as únicas válidas. Daí ela passa a colocar na parede reproduções dessas obras, não colocar nada ou colocar obras ruins, em vez de procurar o máximo de qualidade para as possibilidades do seu bolso.

A alternativa não é apenas "valorizar o artista local". No mundo globalizado, há a possibilidade crescente de circulação internacional de obras, o que é bom tanto para os artistas de países em que eles não são valorizados quanto é vantajoso para o 
comprador, que tem mais opções do que o comércio apenas local impõe. Cresce a importância prática da comparação artística. Cada vez mais as pessoas precisam ter maior clareza sobre as escolhas que podem fazer.

O jornalismo valoriza o aqui e o agora, enquanto a arte consagra o que transcende o aqui e o agora. A literatura é o contrário do jornalismo, mas o modo comum de entendê-la na imprensa tem sido jornalístico. Ele busca reproduzir eventos marcantes do dia a dia de um lugar; ela tem um olhar distanciado do aqui e do agora, pois busca o que é permanente e válido em outros tempos e lugares. Ainda que ela seja propiciada por episódios do aqui e agora, procura constituir um mundo diferente, em que o universal se apresenta de modo concreto, não ideal e sim ideativo, para merecer atenção em outros tempos e lugares, por ter algo a dizer que não seja apenas documento de um aqui e agora. O mesmo vale para as demais artes. No entanto, o ensino, os livros didáticos e dicionários de arte enfatizam na obra o testemunho de um só tempo e lugar. Transformam o secundário em principal e esquecem o mais importante. Em vez de destrinchar o objeto conforme sua estrutura, um só método é imposto.

O jornalismo, que já foi visto como a prostituição da palavra, posta na rua para ser comprada por quem está disposto a pagar por sua banalização numa relação fugaz e sem profundidade, alcança grandeza quando registra no percurso do dia o curso de uma lei histórica: ele se torna, então, história inconsciente do cotidiano. A grande arte é uma historiografia inconsciente coletiva, mas é também um píncaro, só alcançado por poucos. Assim como nos grandes jornais não se costumam publicar textos em desacordo com a política da redação nem que tenham um grau maior de densidade, também não participam do cânone nacional obras que não estejam de acordo com a ideologia implícita em sua estrutura.

\section{CANONIZAÇÃO E VALOR}

O cânone de uma nação ou de uma tendência é um esquema que promove certos autores a evento histórico, escamoteando outros, como se manifestasse uma iluminação divina e não fosse tendencioso. Qualidade não se define por nação, estilo, forma, moral, correção política. É uma diferença que não é quantificável nem definível por conceitos, embora possa ser mostrada. Está além do modo de selecionar, avaliar e 
reproduzir cores e eventos, silenciando mais do que revelando. A posteridade define o que está sendo relevante para ela no passado, esquecendo a maior parte do que se produziu e/ou foi badalado antes.

Se nenhum presente é justo com seus gênios, preferindo promover medianos, o futuro também não será justo. Não só cada presente redefine o seu passado: seus critérios de relevância são problemáticos: o que para uns é demoníaco pode ser divino para outros. A virtude de um é o pecado de outro. Mudanças no presente revisam o passado. O leitor de jornal é o antípoda do clássico: ele só se preocupa com o presente, sem se voltar para as grandes obras do passado. Quem quer se preocupar com grandes obras não pode se ocupar com a medianidade em moda.

O cânone de cada arte, e não só o da literatura, costuma ser definido pela nacionalidade dos autores. Para o que uma obra é, pouco importa, no entanto, quem a fez, onde e por quê. Isso é passageiro, anedótico. Há autores clássicos sobre os quais pouco ou nada se sabe. Confunde-se o acessório com o fundamental. O que realmente importa é a obra em sua qualidade artística, algo que não tem receita nem definição, embora existam em cada estilo, gênero e época diversas regras que são obedecidas quase por instinto.

É mais difícil, todavia, discernir a efetiva qualidade de obras sem se basear em autoria, moda, badalação. Há boas obras de autores pouco reconhecidos, assim como há obras menores de artistas de renome. Há autores com traços bem característicos, maneirismos típicos, reconhecíveis de longe, mas nem por isso grandes artistas. Quando o autor cai no maneirismo de si mesmo, decai a artesão que se copia: torna-se um imitador de si, algo que pode ocorrer mesmo com autores renomados. Grandes obras se destacam à primeira vista, porque são únicas, diferenciadas, inconfundíveis. Há quem tenha um estilo inconfundível, sem conseguir fazer boas obras.

Público e profissionais não questionam o cânone, mesmo que aqui e ali divirjam sobre algum artista ou obra. Ele é aceito como indubitável tabu, algo sagrado, um totem como identidade da tribo. Não há desconfiança. Ele não é visto como interesse do poder. O Estado pretende sediar a moral, como se ele determinasse o valor das obras e dos homens, não fosse um instrumento de dominação social, em que uma minoria se apropria do trabalho da maioria. Toma a cada mês boa parte do trabalho social. Esse direito de cobrar tem por contrapartida moderna o prestar contas do que se 
fez com o dinheiro. O Estado é mais que uma empresa, da qual o cidadão compra bens e serviços pagando impostos. Ele não celebra quem não o ajude a ser celebrado. Ser por ele canonizado se torna, então, um alçamento ao céu da imortalidade, a uma nobreza de espírito, que quer ser parecida com a minoria que se nobilita por abocanhar a maior fatia do produto coletivo. Deuses imortais morrem também. O capitalismo precisa da igualdade, para que todos possam comprar e vender o que quiserem, mas gera crescente desigualdade social. Nunca os ricos foram tão ricos quanto hoje.

Bem diferente de um cânone patrocinado pelo Estado, pela Igreja, por um movimento moralista ou político, é o conjunto de obras que se podem chamar de “clássicas”, cuja seleção é qualitativa, não depende de nacionalidade, não fica restrita a uma época ou um estilo, não é predeterminada por preços de mercado (ainda que se reflita neles). Embora não possa ser convertida em algoritmo, consegue ser um consenso estabelecido entre pessoas sensatas e de bom gosto. Não é apenas um cânone igual aos outros. Podem existir nuances de preferências, mas não se excluem boas obras sem argumentos. Elas podem variar sua participação nesse "acervo universal", mas ele se caracteriza por sua estabilidade. Ele é o que vale a pena ser estudado. O resto não é apenas resto, mas alternativa.

Há uma diferença entre os gêneros artísticos quanto ao caráter único da obra: uma pintura, uma escultura ou uma arquitetura, será sempre uma única e determinada obra, da qual podem ser feitas reproduções ou variantes do autor. Na literatura ou no cinema, o "original" não tem importância, as cópias podem ser múltiplas, sem que se perca o caráter único: a identidade da obra está em sua diferenciação, não na reprodutibilidade técnica. Na música, as execuções variam, de sofríveis a excelentes, e isso afeta o que se vai perceber da obra, sem que a partitura como tal seja afetada. Haver uma reprodução mecânica das obras não afeta seu caráter único, insubstituível. Determinado poema ou filme é aquela obra e não outra, não importa quantas cópias existam; na escultura, na pintura, e na arquitetura, a multiplicação é falsificação ou deterioração.

Pode-se perguntar se, finada a visão católica de mundo, a Divina Comédia de Dante ainda se manteria como grande obra ou se ela poderia procurar se validar fora do horizonte dessa visão. Schopenhauer propôs sua leitura como um grande sarcasmo contra a tirania de Deus sobre suas criaturas, o que parece uma tentativa desesperada de 
redenção dessa obra. O que há de melhor nela é o Inferno, com a ousadia de colocar até papas nos quintos do inferno, de defender a força de uma relação amorosa ou lamentar a prepotência papal em deixar um pai vendo seus filhos morrerem de fome, sem poder fazer nada.

Os lusíadas de Camões é obra escrita por encomenda real, para decantar a formação e expansão de Portugal; como ele perdeu a soberania assim que apareceu a epopeia, ela serviu para mobilizar o patriotismo, conforme era interesse de outras potências que não queriam uma Espanha imensa; depois serviu para legitimar o colonialismo português: com a falência deste, a obra revelou como um discurso oficial, de propaganda lusitana, do que se salvam três episódios independentes, de caráter romanesco: o amor de Dom Pedro por Inês de Castro, que depois de morta foi rainha, assegura a perenidade de um amor e a vingança de um rei que havia sido impedido quando príncipe de afirmar sua preferência pessoal contra as convenções do cargo; o episódio do Velho do Restelo, em que se lamenta o custo do povo para os projetos políticos do Estado; o episódio da ilha dos amores, em que a mulher aparece como recompensa para os esforços do herói.

A Eneida de Virgílio teve três funções ideológicas básicas: legitimar a família Júlio no governo de Roma; justificar a tomada da Grécia pelas tropas romanas; explicar as guerras púnicas como vingança dos súditos de uma rainha abandonada. Todas essas razões são passadas, não geram por si uma obra significativa. A leitura medieval católica, de que no nascimento de Iulo se teria o prenúncio do nascimento de Cristo, num texto escrito antes da dita era cristã, não se sustenta. Agostinho não era bom crítico literário. O que mais gerou pinturas foi o encontro entre Eneias e Dido, surpreendidos por uma tempestade: o encontro amoroso em meio aos perigos da época, a separação como exemplo aos romanos.

Ver no protagonista Hamlet um irresponsável intrigante que articula a aparição teatral do fantasma do pai para tomar o poder - e acaba perdendo o Estado e a vida, acarretando destruição geral ao seu redor - não destrói a peça Hamlet de Shakespeare. Permite que ela seja lida e encenada pelo avesso da tradição. A obra deixa de ser idêntica, ou melhor, percebe-se que a suposta identidade dela é contraditória e que há outras possibilidades de leitura e encenação. 
Exemplos semelhantes poderiam ser encontrados em Sófocles e Eurípides, em Dostoiévski ou Kafka, em pinturas de Goya e Delacroix, em composições de Mozart e Beethoven. Qual é o denominado comum desses fenômenos, que permitem que uma obra seja lida de um modo completamente diverso daquele em que ela foi produzida ou que ela costuma ser lida? Todos se afastam da motivação que comandou a obra, do episódio singular que o conformou, direcionando-se para crises existenciais que atingem todas as épocas e lugares. A Ilíada não é grande só por contar episódios da guerra de Tróia ou a história de Aquiles, mas por estudar concretamente a ira humana, tanto individual, quanto coletiva. Esse estudo não é feito, porém, em termos abstratos ou como um conceito psicológico, mas contrastado com outros afetos, como o amor materno, o amor marital, a amizade entre companheiros de batalha.

Costuma-se supor que as obras constituem o cânone, quando, pelo contrário, é o cânone que constitui as obras canônicas, o gesto semântico implícito na estrutura profunda do cânone é que utiliza autores, obras e aspectos de obras fazendo deles signos para aquilo que ele quer transmitir de modo subliminar, convertendo os receptores em marionetes. Cânone é manipulação. O sentido subjacente funciona tanto mais quanto mais ele fica oculto à consciência crítica do "receptor". Todo paradigma transforma quem o usa em sua marionete. Toda lente faz ver de acordo com seu prisma, sem que seu portador lembre que está com ela.

Esse discurso, oficial, pode acabar contendo variações e contradições de superfície, mas sua estrutura profunda é unívoca. Ela tanto mais funciona quanto menos é percebida. Mais do que impor um modo de ver obras de acordo com a própria ótica, ela quer que se tenha determinada visão da história e da sociedade pátria de acordo com os interesses dominantes. Não quer que se veja de modo crítico as obras, não faz uma seleção de obras que fique num "armário dos venenos", obras que lhe pareçam representar uma ameaça: simplesmente exclui, deixa fora. São dadas opções aos apreciadores, para que prefiram este ou aquele grupo de autores, mas tudo dentro do cânone e da interpretação canonizante.

Para o cânone, a obra é um utensílio, a arte não é o mais importante. O que importa é que se cumpram finalidades. A relação da obra com o contexto é determinada pelos interesses dominantes neste. A obra não tem aí validade como um espaço 
autônomo, em que se exerce uma sobranceira liberdade, capaz de julgar a história e os homens.

O cânone nacional é voltado para a afirmação do Estado, usando aspectos de obras para a montagem de uma suposta história e identidade coletiva, segundo a imagem que a oligarquia quer transmitir de si e da história. Arte não é, porém, narcisismo, nem apenas a sua negação. Narciso não vê a si mesmo, e sim apenas à imagem que tem de si. Um Estado que confia na razão, precisa da arte e da filosofia para desenvolver cidadãos aptos à liberdade. Tudo depende da concepção de homem, portanto, ao que é prioritário ao seu desenvolvimento.

Ainda que o poder sempre tenha usado a arte para obter mais poder, se a vocação da arte é exercer e exercitar a liberdade há uma incompatibilidade básica, uma relação antagônica entre arte e poder. Isso não significa que a preocupação dominante da arte deva ser o combate ao poder, mas que ela não existe para servir ao poder. Ainda que sirva a propósitos externos, a relação básica dela é consigo mesma, ela existe por si e para si, ela é toda estruturada como se servisse a fins, mas não é redutível a determinado fim.

As obras que servem aos fins determinados pelo poder são badaladas pelo poder que elas badalam como se fossem sinos nas catedrais, mas a função básica da arte não é ter função, pois quem tem função é utensílio, enquanto ela é mais que utensílio, algo diferente, que apenas se expõe, não se impõe. Ela é silenciosa como a escultura, mesmo sendo música: ela apenas convida à contemplação, não exige aprovação nem aplauso, embora ambos surjam espontaneamente pelo agrado que ela desperta. Nem todos são dignos da grandeza da arte; a maioria das pessoas não tem disposição interna e disponibilidade para sua contemplação.

Se o poder aparenta promover a arte, mas quer promover a si por ela, ele tem, contudo, o poderio de estiolá-la, deixá-la esquecida. Ainda que ninguém possa ser proibido de fazer uma obra prima, a falta de liberdade, ainda que a obrigue a ser mais inventiva, impede obras possíveis. Subjacente às eras artísticas, há inovações políticas, econômicas e filosóficas. O serviçal do poder deixa de ampliar a liberdade, para ser um pau mandado do governante, que e precisa de quem tenha talento e técnica. $\mathrm{O}$ governante pode se dispor a não atrapalhar a criação, desde que ela esteja, porém, de acordo com o que ele deseja. Reage, no entanto, quando o artista ultrapassa os limites 
do que lhe for conveniente. Para o artista, quanto mais longe do poder, tanto melhor; na prática, quanto mais perto, mais ele se sente prestigiado e importante. Isso o ajuda a se vender. Cidades apenas administrativas, só voltadas para o poder, não são boas para a criação, como também não as que ficam muito longe do poder.

A arquitetura é, porém, uma arte que depende do poder para a construção de obras grandes, entre as quais possam surgir grandes obras. A literatura parece mais livre por só precisar de papel e lápis, mas não é, pois depende de publicação e difusão. O público fica longe desses dilemas, dos quais depende a sobrevivência do artista. A maioria dos profissionais das artes não está preocupada em contestar valores do poder. É possível haver, no entanto, pontos de encontro entre artista e poder. A Torre Digital de Brasília, projetada por Oscar Niemeyer, cumpre suas funções práticas, mas é também uma escultura monumental, que ganha força quando há neblina noturna. Ela transcende o governo que a encomendou.

\section{O SINGULAR E O SERIAL}

O artista produz obras únicas, mesmo quando repete elementos de sua linguagem; o artesão produz em série, mesmo que introduza pequenas diferenças individuais. O pintor costuma colocar seu nome no quadro, perturbando a tela, em vez de colocar no lado avesso, porque está vendendo também o seu nome e para que a obra seja julgada não só por ela e sim por outras em seu nome. O comprador muitas vezes adquire obras por sua inserção numa série, como se fossem artesanato. $\mathrm{O}$ autor ter um estilo peculiar não é garantia suficiente de qualidade. O grande artista se renova, passando a produzir como se tivesse morrido e ressuscitado outro. Ele tem fases. O artesão tende a repetir o mesmo.

Embora o ensino costume reduzir a arte ao aspecto técnico, às expensas da ideia, a técnica é apenas um meio e, por si, não constitui o caráter único, diferenciado da obra. A técnica não pensa, apenas faz. O que nela se pensa é como fazer. Ela é ciência aplicada: incapaz de questionar a teoria, ela é uma consciência prática. A ciência é sua deusa, e nada existe acima dela. O que determina o uso da técnica são razões que não são as da ciência que sustenta a técnica. Esta é apenas um potencial, que por si não percebe quando e como ela deve ser usada, ela não faz a diferença. $\mathrm{O}$ que determina $\mathrm{o}$ 
uso de uma técnica é a hermenêutica do fato, a interpretação que se faz do problema a ser resolvido.

O especialista em um gênero não costuma conhecer as regras que imperam em outras artes, regiões e épocas, não ter boa noção das normas estéticas gerais. A pintura a óleo tem geralmente mais preço que uma litogravura ou serigrafia do mesmo artista, pois, além de gerar uma obra não em série, permite uma expressão mais rica e nuançada. Quanto maior e mais perfeito o número de cópias possível, tanto menos tende a valer cada uma. O preço depende do nome do autor. Enquanto o pintor é pago pelo que faz, o poeta tem de pagar para ser lido. O nome que assina uma aquarela ou um guache pode multiplicar seu preço, mas eles não têm por si o potencial expressivo da pintura a óleo.

Postas lado a lado com outras, as obras melhores se distinguem para o gosto bem formado, e isso não apenas por rótulos de escolas, estilos ou épocas. $\mathrm{O}$ valor não está na técnica em si, nem apenas naquilo que as técnicas possibilitam, mas é determinado, sobretudo, pela qualidade do artista. Ela determina a qualidade da obra, que mostra a qualidade dele. Obras menores de grandes autores costumam ser melhores do que as boas obras dos autores menores.

O computador não vai substituir nem superar a pintura de cavalete. Ele é uma ferramenta técnica. Por si, nada cria. Assim como os pintores renascentistas usavam espelhos e câmeras escuras, assim como mais tarde usaram lentes para projetar imagens na tela, o computador é caminho de novas técnicas, mas o artista ainda é insubstituível. O caráter único da boa obra decorre da diferenciação do artista.

As histórias da arte querem impor às obras uma sequência seriada de escolas, como se elas se sucedessem de modo linear e consensual. A história social da arte é conflituosa. Encarar as escolas como sucessões consensuais não capta a tensa rivalidade e eventual convivência entre diversas técnicas e tendências, lutando pela hegemonia. Serve aos vitoriosos. O cânone iguala o desigual, ao gerar um panteão dos imortais: ele está longe de comparar a qualidade dos artistas. Ele se volta para algumas obras, como registros de uma família real. Aí a plebe, o baixo clero e as classes médias das artes não são considerados. É como se não tivessem existência, não merecessem registro. Ele antes atribui valor às obras do que é o registro de seu valor diferenciado. Esse registro 
repassa hoje à internet, em programas de busca, sites de artistas, galerias e museus, editoras e livrarias, etc.

O modelo mundial dominante nas histórias e no ensino da arte é a ficção de uma história parisiense da arte, não é sequer a real história social da arte lá. Será que já não é limitado um país ser em sua cultura reduzido a uma cidade? Não é pior ainda a submissão de não gauleses ao modelo francês? Mudam os tempos, mudam as metrópoles, não muda a estrutura de dominação. Quem domina a história quer dominar também a história da arte, como se esta fosse exaltação da opressão e não exercício da liberdade.

Se o poder facilita a vida do artista, também impõe limites à criação, desperta disputas acerbas. Comparado ao gênio criativo, todo aquele que apenas faz variações em torno do já criado parece mediano ou medíocre, a não merecer o nome de artista, mesmo sendo um profissional da arte. Na pintura, seria insensato querer que as paredes fossem recobertas de cópias de obras geniais, como se pintores fora do grande cânone não tivessem direito a espaço. A grande arquitetura é única já por sua grandeza. $\mathrm{Na}$ literatura, ler o manuscrito dificulta a leitura, não torna a obra melhor, mas a boa edição aumenta o prazer da leitura. O caráter único da obra não está em haver apenas um exemplar, e sim que se tenha algo diferenciado na obra, por maior que seja sua tiragem. Editoras e bibliotecas costumam conter mais obras medianas e fracas do que um acervo amplo das grandes obras. O ensino deveria se dedicar mais às grandes obras em vez de se dispersar em obras de divulgação e menores.

A criatividade é mais que um exercício da ideia de liberdade: é um árduo combate às coerções de forças contrárias, às restrições da necessidade, uma luta para que a obra use as possibilidades e não seja entravada pelo horizonte limitado da escola, do mecenato, do mercado, do meio. A qualidade não é sempre proporcional ao preço e à fama nem o preço à qualidade. Badalado costuma ser o que atende ao gosto do meio, não o que tem independência diante do poder.

$\mathrm{O}$ artista como que precisa negar a sua vocação à liberdade ao se submeter a quem vai prestigiá-lo, para daí ultrapassá-lo: para ser maior, ele precisa se tornar menor. Se há algo maior nele, sente as peias do que não quer deixá-lo ser grande: precisa fazer das necessidades impostas espaço de invenção. $\mathrm{O}$ autor precisa levar o projeto da obra aos extremos possíveis, para que, como um arco estendido nas duas pontas, possa pelo 
seu centro de equilíbrio ser disparada a resultante mais forte. Mesmo que autores se vendam ao poder, mesmo que isso seja camuflado de vários modos, até com a partilha da crença, mesmo que serviçais menores sejam promovidos a grande, há no artista uma elevação única na criação, que vai se mostrar na grandeza da obra, sobranceira quanto às condições. É uma liberdade interior, que não se entrega ao jugo exterior. Seu preço é a solidão.

Pode-se gerar aí uma penosa contradição: aparecem como grandes os serviçais dos grandes que restringem o horizonte expressivo da arte, inibindo o pleno desdobramento da criatividade. Só não inibe quando não há o que inibir. As historiografias sacralizam então essas obras, tornando-as tabu. O que elas deixaram de dizer se torna território intocável, exatamente para impedir que a partir dele se torne discernível a limitação do território preenchido. Na pintura mitológica, a guerra era representada pelo deus Marte, que aparecia sempre com um rapagão sarado e bonito, como se a verdade da guerra não fosse antes mutilação, fome, horror. Vênus, reunindo os melhores aspectos de diversas mulheres, era um Frankenstein às avessas, um ideal que a mulher real não pode atender. Vênus não seria Vênus se fosse apenas bela.

A questão não é apenas reconhecer diferenças de evolução em diferentes países, mas rever os critérios que definem um país como locomotiva da história, ver que ele é determinado pelos trilhos por onde anda. Controlar os outros não é ser melhor que eles: é apenas ser mais forte ou esperto. Projeta-se uma teleologia na história como se um lugar fosse um deus capaz de determinar o caminho a ser seguido por todos. Procura-se legitimar pela arte o percurso imposto pelo colonialismo como se o preposto fosse proposto por todos. Por toda periferia se interioriza a dominação, se imita e copia. Quanto mais se deve, menos se reconhece a dívida. A arte, que deveria ser expressão da liberdade, é usada para não a ter. Em contrapartida, não se pode ignorar os grandes mestres, mesmo que se concentrem nas metrópoles.

$\mathrm{Na}$ distribuição espacial da arte há uma diferenciação temporal, em que alguns países vivem a história, enquanto outros se arrastam atrás, como se vivessem na préhistória. Isso não impede que países atrasados procurem camuflar a situação inventando uma historiografia nacionalista que busca reproduzir — ainda que não reconheça — não a história real, e sim a suposta história da metrópole. Outro modo de se manter 
dependente é assumir como identidade própria o exótico, ou seja, a visão que a metrópole tem do periférico.

As ideias que as obras melhores expressam não surgem fora de um tempo e espaço, mas não ficam presas a eles. Na história surgem, mudam e se vão. Se ideias se transformam, também instituições que as encenam são reavaliadas. Há deslocamentos e mutações não lineares nas dominantes subjacentes à história.

Se a evolução da arte foi comparada por Chklóvski aos movimentos do cavalo no jogo de xadrez, que, em vez de seguir em linha reta como o bispo e a torre, faz movimentos em zigue-zague: um fator dominante num momento, numa literatura nacional ou até numa obra, torna-se secundário no passo seguinte, enquanto um fator antes secundário passa a preponderar. ${ }^{1} \mathrm{O}$ que aí era irrelevante ou secundário pode se destacar, enquanto o que antes era objeto de polêmica se torna aceito ou é esquecido.

$\mathrm{Na}$ história da arte pode aflorar uma peça não prevista e não só um peão pode se transformar em peça de maior valor como podem surgir autores, fatores, vetores em combinações imprevistas. Se no jogo de xadrez cada contendor tem as mesmas peças, com igual valor - uma guerra sublimada, com chances iguais e lances alternados -, na história não existe essa igualdade inicial nem a obrigação de cada contendor só dar um lance por vez. Pelo contrário, quem pode mais tem peças mais fortes para fazer mais jogadas que o outro.

O que ele reconta é, porém, que venceu o melhor: ele próprio, bem como aquele a quem ele deu apoio porque lhe dava apoio, devendo-se perpetuar sua memória. Assim se forma a história da arte. O renascimento italiano consagra a renovação política da Igreja Católica quando ela ia sendo questionada, mas não se abre ao questionamento em curso. Quanto mais totalizante a situação tanto mais opressiva ela será e menos alternativas hão de restar. No fim, vai parecer haver consenso, uma "escola" de época, um "estilo", porque o sufoco era total, totalitário. Quanto pior para quem vivesse o dissidente, tanto melhor há de parecer.

Nem todo dissidente é portador da verdade, mas ele denuncia a inverdade dominante. $\mathrm{O}$ silêncio do pincel que deixou de pintar encena uma tela ausente a partir da qual se teria de reexaminar a dominação e a repressão havida. Se Botticelli deixou de

1 Ver nota 36. 
pintar quando Savanarola foi queimado e a própria obra dele só foi possível por poderes alternativos em Florença, o que ele fez é um sintoma do que poderia ser feito, mas deixou de ser pelo que fizeram aqueles que o detrataram. A história da arte não é uma sucessão harmônica de achados estilísticos, mas reflete e dá nome a tensões políticas da época. Além de estar atento a essas lutas, é preciso imaginar possibilidades não concretizadas na época. A história real é apenas uma das histórias potenciais, mas não é por ter se mostrado mais forte, necessária, é que ela representa a opção verdadeira.

A concepção do belo e do monumental, o gosto artístico, o patrimônio preservado, tudo é ditado por essa sucessão de senhores, como se fossem um só, retornando o mesmo. Há impasses ocasionais, o empate se resolve no embate, quem pode aniquila o outro. Sua alteridade eventual é então absorvida pelo ditado do mesmo. Isso não é jogo, mas luta de classes, de que inclusive mitos participam. A ideologia forma obras especializadas para se tornar coletiva. Os poderosos se divertem como deuses.

No jogo de xadrez, a semântica de cada peça não reside apenas nos traços de sua fonética: depende da morfologia de sua articulação com outras peças e da sintaxe da combinação dos movimentos. Ainda que raramente se troque uma rainha por um peão, a troca do que aparenta ser menor pelo maior pode ser decisiva. A história social é menos justa em suas decisões.

Quando mudam as constelações sociais e históricas, o que era bom pode vir a ser considerado ruim; e o que era lembrado passa a ser esquecido, enquanto se revolvem os baús do passado para redimir reprimidos. Sempre se busca uma nova adequação aos interesses dominantes, mas a verdade não é a racionalização da vontade. Quando nada é mais stablishment que fingir-se marginal, a marginalidade instituída se torna uma forma mais sutil de exercer o poder. Dá-se voz a quem pouco tem a dizer para que não se ouça a quem mais teria.

A comparação com o jogo de xadrez pressupõe que a história da arte seja um jogo, à base de um equilíbrio de forças, em que as peças de um valem tanto quanto as de outro. A história não é justa. Também não a história da arte, mais ainda quando ela é propaganda disfarçada. Um lado tem mais peças que o outro, tem peças de maior peso. O jogo sempre está desequilibrado, não há apenas combinações diversificadas de um mesmo elenco de fatores. A arte tende a se desenvolver onde há maior poderio 
econômico, passando a servir para legitimá-lo. A comparação sugere que nada se cria em figuras, casas e normas, exceto novas combinações, como um eterno retorno do mesmo, em que tudo já estivesse previsto numa mente divina. Embora se preste assim atenção ao retorno de tópoi e estruturas profundas, a história se tornaria necessária e sagrada, repetição da historiografia vigente. Essa crença atende tanto ao desejo de não se deixar corroer pelo tempo quanto ao endosso da dominação pretérita pelos dominadores atuais.

Mesmo que a graça do jogo esteja na equidade das mesmas peças iniciais, das mesmas regras e da alternância de jogadas, o que se busca na possibilidade infindável de combinações, na recuperação do que parece perdido, na destruição implacável do adversário, é a desigualdade. A história da arte não tem tanta justiça no percurso, mas também acaba preservando apenas poucos. Mais sutil e cruel que o boxe, o xadrez divide o mundo entre bem (eu) e mal (o outro), é capaz da indecência de o cavalo faturar a rainha na frente da torre, buscar a jugular do outro e não parar enquanto não matar o rei. A história da arte não é mais decente.

O artista que auratiza o poder tende a ser apoiado por ele, não só na proporção direta de suas qualidades e sim de sua serventia. Quando se contrapõe, pode ser ignorado ou sufocado. Se ele tem, no entanto, qualidades que façam a sua obra ter grande repercussão, passa a ser vigiado como perigoso e pernicioso. Quanto maiores suas qualidades tanto mais vigilância desperta. $\mathrm{O}$ mais cômodo é ignorar as críticas implícitas na obra. Se o dissidente não pode ser ignorado nem abafado, pode ser eliminado como por acidente. Tudo parecerá acaso, exatamente por não ser. Quanto maior o talento, maior o perigo. Ele é duplamente perigoso para dentro e para fora. Como em geral é apenas ignorado, ele parece inimigo de si mesmo, culpado por tudo o que passa. Esse exílio do presente pode se tornar, contudo, condição de possibilidade para fazer algo que vá além do presente.

A obra é o legado do pensado pelo artista. Se ele delega o pensar a outros, como nas encomendas do poder, ele abdica de pensar a fundo, por si, para só pensar detalhes de execução. Assim ele abdica da arte, para se dedicar ao artesanato. Pensado como gênio, o artista é visto como mensageiro dos deuses, como aquele que intui a essência das coisas: em vez de respeito pela obra, gera-se temor reverencial, que abdica de pensar as obras, vendo seus problemas. 
A lógica do poder é acabar com quem ele supõe que possa ir contra ele. Pensadores foram difamados (Nietzsche, Heidegger), tirados do cargo (Fichte, Hegel, Fiori, Bornheim), censurados (Kant, Marx) ou envenenados de modo aberto (Sócrates) ou oculto (Descartes), tiveram de fugir para não ser mortos (Platão, Aristóteles), ir para o exílio (Eurípides, Ovídio, Voltaire, Ernildo Stein). Tais eventos não são detalhes biográficos secundários nem pertencem apenas ao passado ou a lugares distantes: eles têm tudo a ver com a obra que foi produzida, são índices da diferença entre o que podia ser dito e o que se queria dizer, não se resumem à palavra de quem se beneficiou com o silenciamento. Continuam ocorrendo, tanto mais quanto menos se quer reconhecer. Pensar é perigoso. Ser artista é um risco. Ser perseguido não garante, porém, grandeza nem permanência à obra. Com a morte do autor, ela fica abandonada à própria sorte.

Lavoisier repetiu norma antiga ao dizer que na natureza nada se perde, nada se cria, tudo se transforma. Esse "nada se cria" significava aí, no entanto, "nada se cria a partir do nada", contrário ao pressuposto da criação divina a partir do nada, um nada que seria tudo: a vontade divina. Do nada, porém, nada se cria. Se tudo se transforma, tudo se recria. Criar parte do existente para negá-lo firmando a existência de algo que antes não existia: é uma afirmação por negação.

Nenhum artífice cria do nada. Ele sempre parte de materiais existentes. Se tudo se transforma, nada é absoluto. Não há O Nada: ele seria um ser. Todo ente tem nele a ausência do que ele não é: há nada em tudo. Nenhum ser é o ser. O ser é nada, mas nada não é o ser. Se tudo se transforma, tudo também resulta de criação; se tudo se transforma, tudo acaba se perdendo. Não há obras eternas, ainda que algumas perdurem por séculos.

$\mathrm{Na}$ arte se procura preservar o que merece perdurar por mais tempo, algo que deve ser extraído e retirado do fluxo provisório das coisas por ter significação profunda em outras épocas e regiões. Com o tempo, as obras são relidas de tal maneira que elas já não são mais as mesmas, idênticas ao que elas haviam sido. Obras que parecem inquestionáveis podem longos períodos podem ser esquecidas. Grandes autores, como Homero e Shakespeare, foram esquecidos e desconsiderados durante séculos. Os deuses de hoje são o olvido de amanhã. Os olvidados de hoje continuarão em geral olvidados depois de amanhã. 
Embora os fatores que determinam mudanças de estruturas axiológicas sejam de natureza histórica, a história real é menos uniforme e harmônica do que pretende o discurso dominante. Em cada época há tendências díspares, não apenas uma escola que dita tudo. O que não significa nada para o poder atual ou o que ele vê com maus olhos consegue às vezes sobreviver e ressurgir noutra época ou região. A arte é um espaço para manifestar inquietações e diferenças. Nela se projeta o desejo de que o melhor perdure. Trata-se de um desejo encorpado na obra, não de um fato. Ela administra o desejo, encapsulando-se. Constrói muralhas ao redor de si, distanciando-se do mundo. Assim ela se torna um fato, sem que declare que pretende ser melhor. Frente a circunstâncias hostis, o colecionador tenta construir com a beleza um muro de contenção. Tem nela refúgio e consolo, mas acaba refém do que nela se nega.

O entendimento conceitual permite apreender aspectos lógicos das obras, remetendo a vivências e intuições os transcendem e induzem ao confronto entre elas. Pela comparação se entende a diferença da obra, delineando sua identidade por contraste em relação a obras com as quais ela tem relações de semelhança e divergência. A comparatística é usada para entender essa diferenciação, mas ela deve ser objetiva no método. Não se compara o que um sujeito acha que se pode comparar. Não se trata de associações arbitrárias e sim de correlações fundadas nos objetos, embora a intermediação se dê na vivência individual da obra.

Nos séculos XIX e XX, houve a aceleração dos movimentos de vanguarda, por causa da concorrência típica do capitalismo e pela liberdade que a arte conseguiu ao não ficar mais tão sujeita quanto antes ao mecenato da Igreja ou da aristocracia. A comparatística pode apreender de um modo mais objetivo que os manifestos o que seria a novidade da "vanguarda", mesmo que ela acabe demonstrando quão antigos são os supostos procedimentos novos e as ideias que eles querem transmitir. Enquanto desvenda quão antigos são os modelos retomados, as variantes propostas, as limitações dos horizontes das vanguardas, ela pode demonstrar também, fora do entusiasmo dos adeptos e do horror dos inimigos, o que há de inovador e relevante. Ela é um modo de ir além dos juízos de entendimento, ao induzir à melhor percepção e vivência das obras.

Quando uma obra não é apenas inovadora na forma, mas pensa impasses cruciais da época, ela tende antes a ser neutralizada, esquecida e escondida do que a obter apoio para atuar criticamente e aparecer como "vanguarda". O que se apresenta 
como vanguarda na mídia é o que convém ao stablishment, que lhe dá força para que não apareça quem realmente possa dizer o crucial que incomoda. A inovação formal serve então para requentar conteúdos antigos e demarcar a diferença de um grupo novo no poder. Torna-se importante o desimportante para que não se pense o que mais importa. Isso não torna verdadeira, porém, qualquer crítica nem melhor o que for marginal.

O "vanguardeiro" supõe um exército a segui-lo. Assim não só ele se sente importante como é tornado importante na mídia. A necessidade pessoal de aparecer pode ser inversamente proporcional ao talento. É uma compensação. A qualidade artística de uma obra não é diretamente proporcional à inovação, ainda que o gênio crie normas próprias, desobedecendo a regras consolidadas. Fazer "arte de vanguarda" tornou-se moda no "moderno", como se a pretensão de ser "vanguarda" fosse garantia de qualidade e não reflexo da necessidade de oferecer uma obra diferenciada para conseguir compradores e espaço na mídia. Para a mídia reacionária, é conveniente apresentar como vanguarda o que não vá questionar as estruturas fundantes do poder que ela representa.

A “vanguarda" é uma expressão do mercado, não a negação do capitalismo. Este precisa de inovações na técnica e nos produtos para vencer a concorrência e aumentar a taxa de mais-valia, sua razão de ser. Quem erra o passo fenece. A vanguarda supõe um exército de interesses econômicos, ideológicos e políticos marchando atrás. Mesmo a vanguarda socialista tem sido pensada nesses termos.

A "vanguarda" é antes o oblívio de pré-requisitos artísticos do que um padrão elevado de referência. Supõe que teria valor qualquer coisa que se fizesse conforme seus manifestos. Ela influencia o gosto, de maneira a parecer não ter valor o que não faz parte dela. É uma ditadura sob a aparência de libertação. Profetiza a própria ultrapassagem, mas com a pretensão de que tudo passa por ela. A história da arte abre, porém, caminhos inesperados, não segue o que é ditado.

Um estilo de "vanguarda" tem boa chance de aparecer não só ao servir a interesses do mercado, mas quando serve para desviar a atenção do mais crucial, preenchendo espaços e apresentando como novo o que não é novidade. Tem servido para que não se atente ao que pode ter um efetivo caráter revolucionário. A "vanguarda" pode até servir a um governo que queira usar sua diferença como grife estilística. Logo 
se descobre quão atrasada é sua novidade. Ela tem sido confundida com experimentalismo formal, tanto mais se dizendo revolucionária quanto mais se dispa de conteúdo realmente crítico e inovador.

A história real da arte costuma ser diferente do que conta a história oficial. O último que o poder quer é uma criatividade que faça pensar um mundo alternativo ao implantado e que o faz ser governo. Em crônicas e artigos de jornais, pode-se perceber com nitidez onde os autores param de escrever, onde cessam o seu dizer. Aparece então como escritor quem não tem o que dizer para que não apareça o escritor que realmente diria o crucial. Mesmo que o público não perceba o não-dito, há uma expectativa de ampliação do dizer que não é atendida.

A mídia e as editoras tendem a dar mais espaço a autores disfarçadamente inócuos, mas dizendo que dizem o mais relevante, embora incapazes de expor questões nevrálgicas. Na escola, fica-se apregoando como única arte um conjunto de nomes e obras das oligarquias pretéritas, um discurso inócuo, mas adequado a interesses e perspectivas do stablishment. Como é o único que aparece, parece ser o único que poderia aparecer. Quem não tem alguma forma de poder não consegue concretizar nem difundir sua obra e acaba desistindo.

Esse contexto busca tornar importante um dizer que nada relevante diz à razão crítica, mas reitera a doutrinação do cidadão médio. O texto que se torna discurso oficializado passa a ser leitura obrigatória nas escolas e nos vestibulares. Recebe poder porque dá poder ao poder. O que diz e faz é favorável à política dominante. Os grandes nomes do renascimento italiano foram servos da Igreja Católica, da aristocracia ou da burguesia comercial. Alguma eventual divergência não podia chegar a ponto de questionar a perspectiva oligárquica. Mesmo aí, o artista só conseguia ser artista quando ia além do horizonte previsto pelo mecenas. Fatores externos são interiorizados de tal modo nas obras que eles parecem naturais, e não apenas uma possibilidade entre outras. Só assim conseguem aparecer publicamente.

\section{O SAGRADO E O PROFANO}

O mecenato dita o que o artista deve ou não fazer. Quer ser legitimado pela arte. O que se chama de "arte" medieval, renascentista ou barroca europeia está sob o 
ditado do mecenato. É preciso rever o que resta de arte sob as obras. O design procura auratizar mercadorias, tornando-as mais palatáveis à venda; a auratização do mecenato quer a propaganda do mecenas e da ideologia que ele representa.

O "ser da arte" tem sido determinado assim pela vontade do poder. Correto parecia ser o que lhe era adequado, não aquilo que rompia com interesses da oligarquia civil, militar ou eclesial. Tais obras não perduraram apenas por sua qualidade estética, mas pelo que consagravam. Embora igrejas tenham sido reformadas, reis tenham sido apeados do trono e repúblicas tenham sido proclamadas, não houve uma revisão proporcional dessa arte legada. As novas elites se viram como herdeiras das antigas. Ainda impera o temor reverencial que havia diante da nobreza. Retratos de aristocratas são vendidos em leilões por famílias que deveriam guardá-los. O capitalismo, abrindo a compra e venda de obras de arte para outros estamentos, permitiu o trabalho livre do artista, em contraposição à servidão anterior.

O poder é mais esperto que a maioria que se submete a ele. Ele tem a capacidade de distinguir quem tem talento para fazer sua consagração de modo que não pareça apenas propaganda. A propaganda funciona melhor quando se disfarça de arte, fingindo não ser propaganda. Uma obra religiosa não é artística, pois o que a orienta e constitui é o vetor da propaganda, que tem finalidades bem determinadas. Isso não impede que haja boas obras de arte resguardadas em templos e que seja possível ressuscitar como artísticas obras que costumavam ser consideradas religiosas. Goya pintou de modo realista a rainha de Espanha, que era feia e se reconheceu com agrado no quadro: "essa sou eu”. Consagrou com sua arte a realeza, que depois o exilou.

O Gilgamesh era um texto sagrado para povos da Mesopotâmia; a Ilíada, para os gregos; o Antigo Testamento da Bíblia, para os judeus; o Novo Testamento, para os cristãos; o Alcorão, para os muçulmanos. Cada um acha que só o seu é sagrado. Partindo de vetores históricos são ficções de cunho mitológico e tom elevado. Se a leitura laica de Homero é aceita como correta desde a morte dos deuses helenos e a do Gilgamesh ninguém mais põe em dúvida, a Bíblia não é lida como ficção por judeus e cristãos, pois impera o tabu religioso, sem que se ouse fazer sua releitura. No Alcorão, o discurso exige ser reverenciado como revelação divina, para adquirir autoridade indubitável. A sacralização quer absolutizar o que é relativo. Tanto mais tenta impedir 
que se questione quanto mais problemático é o que afirma. A exegese religiosa tanto mais gera argumentos quanto menos eles se sustentam.

Um texto pode ser sagrado para um receptor e ficção para outro. Não é porque ele fala de divindades que o leitor precisa crer que elas existam e que aconteceu tudo o que se conta sobre elas. Ele tem nele um tom sublime, porque ele se vê no limiar entre o divino e o humano. Cada um considera os outros demais textos sagrados como errados em sua pretensão: embora se refutem mutuamente e procurem a racionalização da crença pela exegese, eles tendem antes a se aliar do que admitir a razão crítica, a se aliar no engano de não se perceberem como a ficção que são. Por mentirem sobre si, pretendem ser verdade absoluta. Cabe à hermenêutica superar a exegese.

Se a dominante textual dependesse apenas da consciência do receptor, este teria o direito de projetar nele o que quisesse. Então cada um poderia atribuir o caráter que quisesse à obra. Ela é, porém, o que ela é, mesmo que diga o contrário. O texto religioso, considerando ser palavra divina, cultiva o estilo elevado. Há uma hipérbole do narrador, que se declara porta-voz de Deus e se arroga o direito de impor sua versão como fato. Quem se declara humilde servo de Deus se acha tão especial que só a um Deus ele pode servir. Ao se apresentar como representante do divino, nega a humildade. É hipocrisia.

Quando uma ficção é vista como texto sacro, perde-se a noção do que ele é. Distorce-se tudo. A exegese se torna deformação, abdica de pensar fazendo de conta que é a única a pensar. Não consegue uma leitura sensata, capaz de perceber contradições e irracionalidades. Quanto mais avança nos detalhes, mais se perde nos pressupostos. Quanto mais explica, mais se complica. Em vez de esclarecer passagens obscuras, perde-se no próprio obscurantismo.

Quando o texto considerado sagrado passa a ser lido como ficção tem-se, com a morte do divino, o reconhecimento implícito da natureza fictícia do texto. Essa morte arrasta consigo o caráter sacro de toda a pintura, escultura, música, encenação ritual ou arquitetura feita em seu nome. Seja na morte dos deuses antigos, na morte de Jeová, de Alá ou dos deuses cristãos, há um imenso naufrágio do divino, que deixa de navegar no dia a dia das pessoas, não tendo mais influência em suas decisões existenciais. Isso obriga a rever o sentido de toda a produção cultural feita em seu santo nome. 
Há o que resiste à releitura e se adapta aos novos parâmetros hermenêuticos, há o que continua submerso no inconsciente coletivo, assombrando sonhos e pesadelos. Como muitos preferem manter a fé numa vida após a morte, pois isso lhe dá consolo, ânimo e sentido, as religiões continuam mantendo seus rebanhos e seu modo de ler. Assim como dentro do templo não se permite uma fala divergente - esse espaço junta o povo, sem ser livre - a mente do crente se proíbe outro discurso. O monoteísmo tem uma forte propensão ao totalitarismo.

Quando o texto ficcional é posto no cânone nacional ou é considerado um grande clássico, ele é transformado em algo sagrado, não se pode mais duvidar dele. A canonização é uma sacralização. O texto considerado sagrado é uma ficção que não se reconhece mais como ficção. A leitura sacralizante é, portanto, um falseamento da natureza do objeto. Quanto mais errônea, tanto mais acha que está certa. Ela precisa ser dogmática para sustentar seu engano. Há um paredão nela em que o argumento não adianta. Não vale a pena insistir. Melhor deixar que continue supondo que está certa e seguir adiante. Ela só admite o que esteja de acordo com o seu parâmetro. Confunde verdade com o que aí seria correto.

A leitura religiosa se considera tão certa em seu paradigma que ela nem se considera projeção de um paradigma: tem certeza de que outra leitura é falsa. Ela quer que se creia no que ela crê, ela não questiona seus pressupostos: faz sua racionalização. Que ela esteja correta dentro de um parâmetro não significa que seja verdadeira. Se uma estátua do deus Hermes foi enterrada pelos sacerdotes em Olímpia como religiosa, para fugir à sanha dos iconoclastas cristãos por volta do ano 100 D.C., como ela foi desenterrada quase dois milênios depois? Como antiga estátua religiosa ou como obra de arte? Se como objeto de culto, seria preciso recrer nos deus antigos para captá-la bem. Se como arte (o que não exclui a dimensão de documento de um culto desaparecido), isso só é possível porque desde o início ela já era arte. Os gregos procuravam representar seus deuses do melhor modo possível: o artístico. É preciso entender o que o deus era como significação, como proposição filosófica, figura ideal do homem, para se conseguir entender a estátua como escultura. A crença distorce a vivência ao traduzi-la a seus termos.

Para se aproximar da verdade é preciso que a coisa tenha a liberdade de se mostrar plenamente, assim como o sujeito precisa ter a liberdade interior para permitir 
que ela se exiba em sua diversidade, que pode ser adversa e perversa. O que está na coisa não é ditado pela consciência, assim como algo é belo só porque se supõe que seja. Se o gênero artístico e a natureza da coisa fossem ditados apenas pela "consciência do receptor", então se tornaria arbitrária a relação entre a função estética e as demais funções, a arte seria redutível a impressões.

Por que a ficção pode ter a pretensão de ser mais verdadeira do que religião? A religião finitiza o infinito, para poder se apresentar como voz da infinitude e assumir o poderio e as benesses da particularização. Ela se apresenta como o que ela não é. A ficção tem ao menos a sinceridade de se apresentar como ficção, sem a pretensão de ser a realidade nem a última palavra que possa ser dita sobre qualquer assunto. Ela é mais verdadeira por não querer se passar como realidade, ainda que ela reproduza aspectos da realidade. Para ser verdadeira, ela não pode ser apenas cópia, pois precisa modificar e transformar dados referenciais para conseguir imprimir-lhes cunho significativo.

Ainda que se disfarcem de crenças coletivas, os mitos antigos também eram ideologias de classe, assim como o são os mitos atuais. Há mitos específicos, como o mito jurídico, o mito da arte clássica, o mito do eurocentrismo. Embora os helenistas se inclinem a acreditar nos mitos antigos, a crença nos deuses é hoje, para a tragédia grega, antes um prejuízo à validade da obra do que aquilo que lhe dá efetivo sentido. Ela pode ser levada em conta na interpretação, mas não é ponto de partida nem de chegada. Não é uma abertura racional ao imponderável, a tudo o que não pode ser previsto e entendido por conceitos, mas uma explicação falsa, que atrapalha o bom desenrolar da ação e o entendimento do que é encenado. É preciso ver o que está sendo repassado através deles. Não existe "verdade revelada pelos deuses", não existe "vontade divina", não existe "fatalidade".

O helenismo não costuma ter distância crítica quanto ao mundo grego antigo, por exemplo, em relação ao escravismo, à discriminação contra estrangeiros, a repressão às mulheres, as crenças religiosas, a aristocracia de sangue. Ele acredita que os gregos acreditavam, e isso lhe basta, não vê aí um problema. Saindo-se disso, não se pode mais fazer uma "arte neoclássica" nos moldes do século XVIII, replicando as crenças, assim como se torna frágil toda produção estética baseada em pressupostos religiosos que a razão crítica não pode aceitar. A comparatística não costuma aprofundar tais questões, 
ainda que básicas. Ela é um instrumento da filosofia tanto quanto ela precisa se valer desta para intuir as questões em que mergulha seus dedos.

Os romanos mantiveram e reproduziram os templos gregos, rebatizando os deuses. Os cristãos antigos eram iconoclastas e destruíram boa parte do patrimônio cultural helênico. Em alguns casos, a adaptação de templos a igrejas fechou as colunas externas e demoliu a cela com a estátua da divindade para colocar o altar. Equivale a poupar a vida do prisioneiro de guerra para fazer dele um escravo. Todo o espaço passou a ser ocupado pela voz do padre, sem lugar abrigado no templo para se conversar. O monoteísmo fez uma arquitetura totalitária, que vedava todo o espaço a uma voz estranha à do sacerdote.

O que, em Paris, havia sido um palácio de governo, feito para expressar a grandeza ideal do rei, foi transformado em museu, que abriga a grandeza da arte; o que era um templo cristão pode ser transformado em local de shows, ringue de patinação ou restaurante, como vem acontecendo aos milhares na Europa ocidental. Um palácio das artes pode virar supermercado e depois usado como centro de culto; o que era escultura religiosa, pode se tornar peça de decoração. Assim, em diferentes gêneros, as obras mudam de função.

Espera-se, no entanto, que o caráter artístico seja algo permanente, mesmo sendo uma identidade construída em meio a diferenciações. Ele não é "função", pois esta é uma conexão de meios a fins. Tais conexões servem para explicar utilidades e manipulações ideológicas, mas não conseguem abranger o diferencial artístico. Enquanto predominar a leitura religiosa de uma obra considerada sacra, ela não chega a ser vista como arte, embora haja elementos estéticos presentes: o estético não é aí uma estrutura válida por si, pois é apenas um trampolim para algo tido por mais elevado: propaganda do dogma, difusão da fé.

A filosofia da arte também considera a obra como instrumento, mas da filosofia, para a exposição do que ela considera ideia: usa a obra como trampolim para chegar ao espírito absoluto (mesmo que não exista). Nesses casos, a liberdade da obra é atrelada a interesses e pontos de vista alheios, é usada para reforçar preconceitos. Além de poderem ser arte arquitetônica, templos podem abrigar obras de arte, até obras que sejam capazes de ir além do horizonte da propaganda religiosa, assim como obras postas 
em palácios da realeza, quando eles foram transformados em museus, puderam ser apreciadas sob outro vetor.

Não se trata, porém, de mera alteração de "dominante", seja externa, pela mudança de regime política, seja interna, pela passagem de obra de culto a artística. Esta é uma explicação que parece pragmática, mas é banalizadora. Seria como se a verdade da obra residisse no sentido que lhe fosse atribuído, ou seja, existiria na consciência do autor ou do receptor, individual ou grupal, sendo reduzida às dimensões do contexto. A arte é uma coisa objetiva, pois existe em forma de obras concretas. Nunca foi só "metafísica".

A obra de arte, como ente corpóreo, resistiu à tendência neoplatônica de valorizar só o abstrato e espiritual, em detrimento do "material". A pretensão hegeliana de chegar ao Espírito Absoluto, sendo a arte algo primitivo por não ser apenas abstrata, é enganosa: não há nada absoluto, não há totalidade, não há espírito sem corpo. No estudo da arte, a Estética está para o corpóreo assim como a Filosofia da Arte está para o espiritual: a superação do neoplatonismo exige a superação de ambas. A arte não será substituída pelas ciências porque ela tem um alcance reflexivo concreto que não é dado a estas e também não à filosofia.

Não basta um sujeito, individual ou coletivo, por mais poderoso que seja, decretar que algo é arte. Com a astúcia da raposa ou/e a força do leão, pode impor sua opinião. A verdade aí está na vontade do poder. Ele impõe porque isso é do seu interesse: o poderoso é escravo dos interesses do poder. A arte é, no entanto, algo interessante, sem ser interesseira nem se confundir com interesses. Como todo objeto é mediado pelo sujeito, não basta declarar que o sujeito apenas reconhece o que a obra é. Os crentes gregos podiam não perceber o caráter ficcional da obra de Homero assim como a Idade Média não reconheceu a importância dele como artista. Não se reconhecer, por longo tempo e em diversos meios, a natureza e o sentido de uma obra não faz com que ela seja ou deixe de ser o que ela é.

Tanto o "texto sagrado" propõe ser a revelação de uma "verdade superior" quanto se acredita que seja a vontade divina tornada palavra. A definição filosófica - de Aquino a Hegel - de que o belo é a aparição sensível da ideia - é teológica e neoplatônica: o espírito divino que apareceria no texto sacro é traduzido pela aparição da ideia na coisa bela. Do mesmo modo, o espírito divino se teria feito carne em Cristo, 
o abstrato se tornaria concreto Não existe, porém, o mundo das ideias como algo anterior a qualquer existência, como não existe um deus e um céu acima dos homens que os imaginaram. Aquino declara sua crença em Cristo sob a aparência de definir o belo. É uma transposição.

A grande obra de arte não se deixa reduzir a conceitos, crenças ou sentimentos primários. Ela não é um cocho em que o filósofo vai pastar ideias. Ela não é a demonstração de um conceito, de um dogma, de um sentimento fixo. Ela é sempre contraditória, uma abertura para a infinitude, a intersecção do ontológico com o ôntico. Ela está fora do puro entendimento conceitual, embora precise de conceitos para ser construída e melhor percebida.

O conceito deriva da seleção de elementos idênticos que se encontram entre entes cujas percepções são diversas: ele é uma definição finita, na qual cabe um número indefinido de fenômenos. Ele é analítico, finito, claro e distinto. A ideia é sintética, com abertura para a infinitude, complexa em sua abrangência, recusando-se a se deixar definir por conceitos. A ideia de liberdade só tem sentido quando contraposta à necessidade como algo que a integra.

O conceito está para o entendimento assim como a ideia está para a razão. Sendo a ideia mais complexa e elevada que o conceito, este não consegue defini-la, pois, quando tentar fazer isso, ele a reduz ao conceitual e trai a sua diferença. A ideia exige mais esforço de apreensão do que o conceito e não pode ser reduzida à lógica formal. Ela não é apenas um conglomerado conceitual e não é uma estrela fixa do mundo das ideias ou da mente divina. Ela envolve sentimento, imaginação, vivência, empatia, disponibilidade, além de tudo o que se exige para chegar ao conceito.

A grande obra de arte ou de filosofia não só expressa ou exprime ideias como algo já existente antes dela. Pelo contrário, é com ela que essas ideias passam a ter existência. Há algo de "sagrado" na "ideia", não só pelo respeito que merece como algo único, mas por ser o nível mais elevado que o homem é capaz de gerar. O dogma resulta da desistência de pensar. Ele fracassa no esforço de ascender a esse plano mais elevado da ideia, mas acha que o transcendeu por crer no mistério do saber divino. Quem fica preso a crenças, não tem a abertura e a energia para se alçar a esse nível mais complexo e amplo das "ideias". Dizer que a Bíblia é literatura não é rebaixá-la, mas dar-lhe a 
oportunidade de ser o que ela é: uma forma de arte, ainda que isso não seja admitido pela exegese religiosa. Tem-se nisso, porém, outra concepção do que seja a ideia.

A arte comparada poderia ajudar a entender os gêneros e a transição entre eles, já porque compara arte com arte e com o que não é arte. Ela precisa se abrir para o que opera com signos, ler o mundo como significativo. $\mathrm{O}$ poeta percebe a linguagem dos entes e das cenas para preservar sua significação a outros. É preciso dar o passo complementar da semiótica da cultura, introduzindo sistemas não artísticos na comparação e entendendo que arte é linguagem não redutível a esquemas formais de signos. As palavras não são signos arbitrários, mas socialmente necessários entre os falantes: não produtos de convenções formais e sim das relações entre trabalho e realidade. Imagens podem ser alteradas e sua mentira pode ser proporcional à semelhança que pretendem ostentar com a coisa significada. Não cabe uma hierarquia entre identidade e não identidade de signo e coisa significada, já porque são diferentes por natureza.

A coisa não é "significada", no sentido de que o signo lhe daria significação. Pelo contrário, ela é que gera a significação na medida mesma em que representa a verdade da coisa aparecendo. O signo não se divide apenas em significante e significado, como se este fosse gerado por um jogo de diferenças entre elementos daquele. É um engano formal. O sentido de um signo pode ser o contrário do significado na ironia. O "significante" não gera a significação, esta não surge dentro do suposto sistema fechado do signo.

O pragmatismo americano se engana ao supor que a verdade resulta sempre da comprovação da hipótese na prática: o médico pode diagnosticar uma laringite e receitar um antibiótico, que vai fazer efeito sobre a infecção pulmonar não diagnosticada por ele: o tratamento é correto para um diagnóstico insuficiente. Outras vezes se sabe que determinados tratamentos funcionam, sem que se saiba bem por quê. Transferir para a técnica a verdade é esquecer que ela está antes na ciência do que em sua aplicação.

Não há um "código" único para conhecer arte, mas é preciso dominar diversos códigos para entendê-la. Não basta, porém, entender: é preciso sentir, imaginar, intuir, construir. Mais que língua, ela é linguagem. Ler obras de arte como textos é parcialmente válido, já que diversos códigos participam de sua constituição. A semiótica não resolve a grande arte. O problema reside em querer reduzir as obras a 
códigos, sem perceber que elas fazem um uso muito próprio deles, para construir algo que não cabe mais neles nem na "semiótica" que se entenda como aplicação de um sistema a priori de deciframento. É preciso um passo na direção de uma hermenêutica da arquitetura, da pintura, da escultura e assim por diante: as obras são "interpretações do mundo mediante um heterocosmos". É preciso evitar a exegese dogmática, que busca sempre racionalizar crenças, sendo incapaz de questionar os pressupostos para entender com mais acurácia o texto.

Na escola de Praga se definiu a arte como a obra em que a função estética seria dominante, sendo esta definida simplesmente como o não-utilitário. Isso permitiria distingui-la de obras em que elementos estéticos são utilizados como fatores secundários. Não é por algo não ser útil que se torna arte. A arquitetura modernista caiu várias vezes na falácia de considerar a obra tanto mais artística quanto menos funcional fosse. Embora a obra de arte não se reduza a uma utilidade determinada, isso não significa que ela não serve para nada.

Arte não se reduz a função. Esta é uma conexão de meios a fins. Isso confunde a obra de arte com o utensílio. Se arte não se reduz a função por não ser utensílio, também não tem sentido falar em “dominante". Um martelo tem a função dominante de pregar pregos, mas pode servir também para arrancar pregos, martelar o dedo, golpear a cabeça do inimigo. Ele sempre "funciona" para algo. Um templo religioso também cumpre suas "funções de culto" e, como tal, ele não é arte. Um palácio pode abrigar um governo ou um museu: consegue desempenhar funções diferentes.

A chamada "função estética", como projeção do princípio de equivalência do eixo paradigmático sobre o eixo sintagmático, define a arte como dicionário. Embora haja equivalências e harmonias na obra de arte, seu funcionamento não é função nem estética. A "função estética" não constitui sua "dominante", já porque a arte, como exercício da liberdade, não quer dominar; e ela não quer ser "função": o estético é uma não função, mesmo que a obra não seja antifuncional. Um palácio é um utensílio enquanto algo planejado e usado para atender a necessidades de quem vai nele exercer atividades de governo, mas só se torna arte se consegue expressar algo como a grandeza daquilo que nele se faz. Ele se torna monumento, grã-escultura.

Arte não se impõe: ela se expõe. A função de algo é um funcionamento instrumental, um meio que serve para atender a uma finalidade, que a constitui e lhe dá 
validade. A função impõe a forma ao utensílio. Ele é tanto melhor quanto mais sua forma e seu material servirem à função que ele deve desempenhar.

A obra de arte não é feita para atender determinada utilidade, embora ela seja estruturada de modo tão organizado e detalhado como se toda ela fosse feita para cumprir funções. Ela é perfeita quando não se pode retocar essa adequação a algo que não é prático, imediato. Ela é significativa, ainda que não redutível a um significado único. Ela busca expressar e concretizar de modo único uma ideia complexa, contraditória e intangível.

O estético não é redutível a uma finalidade, pois a arte se constitui num horizonte que transcende qualquer finalidade imediata. Por mais finalidades que sejam atribuídas a obras de arte - as arquitetônicas são as que melhor evidenciam serem feitas para atender a funções -, a dimensão estética nelas se constrói a partir do que é útil e funcional, para ir significativamente além. Há uma diferença entre um galpão e uma obra arquitetônica artística. Ela é mais que o funcional, algo que é festa, celebração, exaltação vital: tem, por natureza, um caráter muito diferente do que é apenas utilitário. Ela está para o feriado como o utensílio está para os dias úteis da semana. Não vale, porém, a falácia de se considerar mais artística a arquitetura que pior cumpre funções práticas.

A arte não é apenas um documento de uma época ou lugar, ela não se deixa reduzir a peculiaridades de um espaço e tempo. Pelo contrário, ela passa a valer quando consegue, em sua concretude, representar, utilizando-se de todas as figuras que a retórica, a semiótica e a estética possam desenvolver, algo que é mais "ideal", mais "ideativo", mais "universal" do que tais conceitos conseguem apreender. A redução da obra a documento convém ao horizonte de quem não consegue ou/e não quer apreender a conjunção de sentimento, compreensão, imaginação e liberdade que nela interagem e se conjuminam num processo que não é redutível a qualquer um desses aspectos. A grande arte se dá num patamar mais elevado que o entendimento conceitual, a afetividade mais ou menos inibida, o gosto da moda, a propaganda comercial, a promoção de governos, igrejas e grupos. Ela pode ser a culminância do humano. 